\title{
sciendo
}

\section{GROWTH, GUT MORPHOLOGY AND MICROFLORA OF AFRICAN CATFISH Clarias gariepinus FED MUSHROOM (Pleurotus pulmonarius) STALK MEAL SUPPLEMENTED DIETS}

\section{Oluwakemi Abimbola Adejonwo ${ }^{1 *}$, Bamidele Oluwarotimi Omitoyin ${ }^{2}$, Emmanuel Kolawole Ajani $^{2}$, Olugbenga Adeniran Ogunwole ${ }^{3}$, Siyanbola Adewumi Omitoyin²}

${ }^{1}$ Department of Fish Technology and Product Development, Nigerian Institute for Oceanography and Marine Research, Victoria Island, Lagos State, Nigeria

${ }^{2}$ Department of Aquaculture and Fisheries Management, University of Ibadan, Oyo state, Nigeria

${ }^{3}$ Agricultural Biochemistry and Nutrition Unit, Department of Animal Science, University of Ibadan, Oyo State, Nigeria

*Corresponding Author, Email: adejonwokemi@gmail.com

\section{ARTICLE INFO}

Received: 6 November 2019

Accepted: 26 April 2020

\section{ABSTRACT}

Effects of dietary supplementation of Pleurotus pulmonarius stalk meal on growth, gut microflora and intestinal morphology of Clarias gariepinus were assessed in this study. The stalk meal was incorporated at $0.0 \mathrm{~g} / 100$ $\mathrm{g}$ (Control), $2.5 \mathrm{~g} / 100 \mathrm{~g}$ (PSM 2), $5.0 \mathrm{~g} / 100 \mathrm{~g}$ (PSM 3), $7.5 \mathrm{~g} / 100 \mathrm{~g}$ (PSM 4) and $10.0 \mathrm{~g} / 100 \mathrm{~g}$ (PSM 5). Clarias gariepinus ( $\mathrm{n}=375$ ), with an initial weight of $10.84 \pm 0.04 \mathrm{~g}$, were allotted at $25 \mathrm{fish} / 60$ litres of water in a completely randomised design for each diet treatment in triplicate. Feeding trial was conducted for eight weeks. Weight gain, specific growth rate, survival rate, feed intake and feed conversion ratio were not significantly different across all diet treatments. However, the production performance index of the fish and protein efficiency ratio were higher in fish fed PSM 3 diet than other treatments. Total viable bacteria count in the gut ranged from 7.56 (PSM 2) to $8.34 \log _{10} \mathrm{cfu} / \mathrm{g}$ (PSM 4), while lactic acid bacteria count was between 5.00 (control) and $7.03 \log _{10}$ cfu/g (PSM 3). Escherichia coli were identified in the gut of the control group but were not detected in those fed supplemented diets. More colonies of Salmonella and Vibrio species were observed in the control but fewer colonies in the diets supplemented groups. The proximal, middle and distal villus length, proximal, middle and distal cryptal depth, proximal and distal absorption area of fish fed supplemented diet were higher than those of the control. Conversely, proximal, middle and distal villus width and middle absorption area were not significantly different. In spite of observable favourable gut microflora and gut histomorphology of fish fed supplemental $P$. pulmonarius stalk meal diet, these attributes did not manifest in growth performance indices.

Adejonwo, O. A., Omitoyin, B. O., Ajani, E. K., Ogunwole, O. A., Omitoyin, S. A. (2020): Growth, gut morphology and microflora of African catfish Clarias gariepinus fed mushroom (Pleurotus pulmonarius) stalk meal supplemented diets. Croatian Journal of Fisheries, 78, 79-90. DOI: 10.2478/ cjf-2020-0008. 


\section{INTRODUCTION}

The culture of fish requires the use of formulated diets which should not only contain necessary nutrients but also complementary feed additives to keep the fish healthy, favour growth and promote environment-friendly aquaculture (Ajiboye et al., 2012). Dietary supplementation with feed additives such as immunostimulants, probiotics and prebiotics has been found to improve immunity, feed efficiency and growth performance of fish (Ganguly et al., 2010).

The potential of oligosaccharides and dietary fibers from other sources such as fungi apart from plants as prebiotics may have interesting applications in aquaculture to stimulate gut health as well as to suppress deleterious bacteria in the gut of fish. Prebiotics have been reported to reduce the density of pathogenic micro-organisms in the gastrointestinal system of fish (Reza et al., 2009). They also positively alter the morphology, structure and functions of the intestinal mucosa of livestock and poultry (Samal and Behura, 2015).

Mushrooms are rich in non-digestible dietary fibre and polysaccharides such as chitin, $\alpha$ and $\beta$-glucan, mannans, xylans and galactans, hemicelluloses and heteropolysaccharides (Aida et al., 2009), which modulates a wide range of biological activities. The stalks of mushrooms have been reported to be rich in carbohydrate and fiber and constitute 25 to $32 \%$ of the weight of fresh mushrooms (Chou et al., 2013). They are considered waste products from the mushroom industry which are usually discarded as low economic value animal feed and compost. Mushroom stalk meal could act as a prebiotic that may enhance the growth and survival of probiotics and favourably alter the morphology of the gastrointestinal tract of fish.

The previous studies documented on the diet utilisation of mushroom stalk meals include evaluating the growth performance of Clarias gariepinus and Oreochromis niloticus fingerlings fed partial and complete replacement of rice bran with $P$. florida stalk meal (Muin et al., 2013 and Muin et al., 2014), partial and complete replacement of fishmeal with Pleurotus sajor caju stalk meal and soybean meal in tilapia fingerling diets (Muin et al., 2015), P. sajor caju stalk meal as a prebiotic on growth performance of red tilapia fingerlings (Jabir et al., 2012) and the effect of raw polysaccharide extract from mushroom stalk waste on growth and $\mathrm{pH}$ perturbation induced-stress in $O$. niloticus (Ahmed et al., 2017). Studies on the assessment of mushrooms and their stalk meals on gut microbiota and morphology have been conducted on broiler chickens (Fard et al., 2014; Kavyani et al., 2014) and turkey poults (Giannenas et al., 2011). However, there is a dearth of information on the dose-response relationship of mushroom stalk meal as a prebiotic supplement on growth performance and its effect on the gut microflora and gut morphology in cultured fish.
Hence, this study was carried out to determine the effect of dietary supplement of $P$. pulmonarius stalk meal on the growth performance and gut ecology of $C$. gariepinus juveniles.

\section{MATERIALS AND METHODS}

\section{Processing of mushroom stalks}

The stalks of mature cultivated mushrooms ( $P$. pulmonarius) were air-dried for about two weeks, milled in a blender, bagged and stored in the refrigerator at $4^{\circ} \mathrm{C}$ until the feeding trial.

\section{Experimental diet formulation}

Semi-purified diet was formulated with varying inclusion levels of $P$. pulmonarius stalk meal at $0 \mathrm{~g} / 100 \mathrm{~g}$ (Control), $2.5 \mathrm{~g} / 100 \mathrm{~g}$ (PSM 2), $5.0 \mathrm{~g} / 100 \mathrm{~g}$ (PSM 3), $7.5 \mathrm{~g} / 100 \mathrm{~g}$ (PSM 4) and $10.0 \mathrm{~g} / 100 \mathrm{~g}$ (PSM 5). The proximate analysis of the experimental diets was determined according to the standard method of (AOAC, 2002). The proximate composition of the experimental diet is presented in Table 1.

\section{Experimental fish and feeding trial}

Juveniles of $C$. gariepinus weighing $10.84 \pm 0.04 \mathrm{~g}$ were acclimatized and fed commercial diet for two weeks until well adapted with the experimental conditions. The feeding trial commenced with a total of 375 healthy juveniles stocked at 25 fish/60 litres of water in 85-litre rectangular plastic tanks in triplicate for each diet treatment. The feeding trial was conducted over 8 weeks using a completely randomized design. Diets were fed at $3 \%$ body weight of the fish twice daily between 8.00 to 9.00 am and 4.00 to $5.00 \mathrm{pm}$. The experiment was carried out under static renewal conditions with total water exchange every two days throughout the study period. Fish mortality was monitored daily while weight gain of fish in each tank was determined biweekly and the daily ration was adjusted accordingly. The growth parameters were determined biweekly and nutrient utilization parameters were determined at the end of the feeding trial.

\section{Growth performance and survival rate}

Growth performance and survival rate were calculated according to the equations:

Weight Gain $(\mathrm{g})$ = final weight of fish $(\mathrm{g})$ - initial weight of fish (g)

Specific Growth Rate (\%/day) $=(\ln$ final weight of fish $-\ln$ initial weight of fish $\times 100$ ) / Days of feeding

Survival $(\%)=$ (Number of live fish $/$ Number of fish stocked) $\times 100$

Production performance index $=$ Survival rate $x$ (Final body weight-initial body weight) / Duration of feeding 
Table 1. Ingredients and proximate composition of experimental diets fed to Clarias gariepinus $(n=375)$

\begin{tabular}{|c|c|c|c|c|c|}
\hline Ingredients (g/100g of feed) & Control & PSM 2 & PSM 3 & PSM 4 & PSM 5 \\
\hline Casein (g) & 36.58 & 36.58 & 36.58 & 36.58 & 36.58 \\
\hline Gelatin (g) & 7.32 & 7.32 & 7.32 & 7.32 & 7.32 \\
\hline Corn starch (g) & 35.35 & 35.35 & 35.35 & 35.35 & 35.35 \\
\hline Fish oil (g) & 2.00 & 2.00 & 2.00 & 2.00 & 2.00 \\
\hline Soyabean oil (g) & 3.00 & 3.00 & 3.00 & 3.00 & 3.00 \\
\hline Fish vitamin-mineral premix* $(\mathrm{g})$ & 3.00 & 3.00 & 3.00 & 3.00 & 3.00 \\
\hline Dicalcium Phosphate (g) & 1.00 & 1.00 & 1.00 & 1.00 & 1.00 \\
\hline Calcium Carbonate (g) & 0.25 & 0.25 & 0.25 & 0.25 & 0.25 \\
\hline Carboxyl methyl cellulose (g) & 1.50 & 1.50 & 1.50 & 1.50 & 1.50 \\
\hline Non Nutritive Cellulose (g) & 10.00 & 7.50 & 5.00 & 2.50 & 0.00 \\
\hline Pleurotus pulmonarius stalk meal (g) & 0.00 & 2.50 & 5.00 & 7.50 & 10.00 \\
\hline \multicolumn{6}{|c|}{$\begin{array}{l}\text { Proximate composition of experimental diet fed } \\
\text { Clarias gariepinus (g/100g) }\end{array}$} \\
\hline Crude protein & $39.25 \pm 0.96$ & $39.71 \pm 1.01$ & $40.03 \pm 0.90$ & $40.27 \pm 1.07$ & $40.42 \pm 1.15$ \\
\hline Ether extract & $3.24 \pm 0.13^{\mathrm{a}}$ & $3.46 \pm 0.14^{b}$ & $3.53 \pm 0.11^{b}$ & $3.75 \pm 0.13^{c}$ & $3.84 \pm 0.10^{c}$ \\
\hline Crude fibre & $9.09 \pm 0.02^{\mathrm{e}}$ & $8.21 \pm 0.07^{d}$ & $6.67 \pm 0.22^{c}$ & $4.26 \pm 0.07^{b}$ & $3.03 \pm 0.01^{\mathrm{a}}$ \\
\hline Ash & $3.16 \pm 0.25^{\mathrm{a}}$ & $3.34 \pm 0.20^{\mathrm{ab}}$ & $3.64 \pm 0.14^{\mathrm{abc}}$ & $3.94 \pm 0.11^{\mathrm{bc}}$ & $4.06 \pm 0.10^{c}$ \\
\hline Moisture & $8.13 \pm 0.17$ & $8.18 \pm 0.23$ & $8.15 \pm 0.21$ & $8.29 \pm 0.26$ & $8.25 \pm 0.19$ \\
\hline NFE & $36.88 \pm 1.04^{\mathrm{a}}$ & $37.11 \pm 0.964^{\mathrm{ab}}$ & $37.98 \pm 1.13^{\mathrm{ab}}$ & $39.51 \pm 1.10^{\mathrm{bc}}$ & $40.32 \pm 0.99^{c}$ \\
\hline
\end{tabular}

The above values are means of triplicate data; Means \pm SD with different superscript within the same row are significantly different $(P<0.05)$.

Note: Control, PSM 2, PSM 3, PSM 4, PSM 5 = Pleurotus pulmonarius stalk meal at 0, 2.5, 5.0, 7.5, and $10 \mathrm{~g} / 100 \mathrm{~g}$ inclusion level; NFE - Nitrogen free extract.

${ }^{*}$ Fish vitamin-mineral premix: $2.5 \mathrm{~kg}$ contains vitamin $\mathrm{A}: 12.5$ million international unit (MIU), vitamin $\mathrm{D}_{3}: 2.5 \mathrm{MIU} ;$ vitamin $\mathrm{K}_{3}: 2 \mathrm{~g}$; vitamin $\mathrm{B}_{1}: 3 \mathrm{~g}$; vitamin $\mathrm{B}_{2}: 5.5 \mathrm{~g}$; vitamin $\mathrm{B}_{6}: 5 \mathrm{~g}$; vitamin $\mathrm{B}_{12}: 0.25 \mathrm{~g}$; Niacin: $55 \mathrm{~g}$; Calcium pantothenate: $11.5 \mathrm{~g}$; Choline chloride: 500 g; Folic acid:1 g; Biotin: $0.08 \mathrm{~g}$; Manganese: 120 g; Iron: 100 g; Zinc: 80 g; Copper: 8.5 g; lodine: 1.5 g; Cobalt: 0.3 g; Selenium: 0.12 g; Antioxidant: 120 g

\section{Determination of feed intake and diet utilisation}

At the end of the feeding trial, feed intake and diet utilisation parameters were calculated according to the equations:

Feed intake $(\mathrm{g} /$ fish/day $)=$ Amount of feed fed to fish per day.

Feed Conversion Ratio $=$ Weight of dry feed fed $(\mathrm{g}) /$ Wet weight gain of fish (g)

Protein efficiency ratio $=$ Wet weight gain of fish $(\mathrm{g}) /$ (Protein intake (g)

\section{Water quality analysis}

The water quality parameters namely $\mathrm{pH}$, dissolved oxygen, ammonia and nitrite were monitored biweekly using LaMotte Freshwater Aquaculture Test Kit. The water temperature in the experimental tanks was measured using mercury-in-glass thermometer calibrated in degree Celsius $\left({ }^{\circ} \mathrm{C}\right)$. The thermometer was dipped in the water in the fish tank for temperature measurement and the temperature was recorded after two minutes. 


\section{Gut microbiological analysis}

The gut of $C$. gariepinus juveniles was obtained by dissecting the fish under aseptic conditions with sterile scalpels and forceps. The gut was scooped into sterile McCartney bottles on ice from the five different diet groups in triplicate for microbiological analysis. The guts were homogenized within one hour of collection with ceramic mortar and pestle under aseptic conditions. The homogenized gut was enriched by weighing $5 \mathrm{~g}$ of homogenized gut into $45 \mathrm{~mL}$ of peptone water $(\mathrm{pH} 8.5)$. About $5 \mathrm{ml}$ of the enriched medium was measured into 45 $\mathrm{mL}$ of De Man, Rogosa and Sharpe (MRS) broth (pH 5.5). The broth culture media containing the gut contents was incubated for 12 hours at $30^{\circ} \mathrm{C}$ before subsequent serial dilutions of the samples in $9 \mathrm{~mL}$ aliquots of sterile distilled water to a dilution factor of $10^{-3}$ and $10^{-5}$ according to the method of Ogunse and Olabode (2009). The pour plating method was employed in the culturing of the gut content from the peptone enriched medium on different sterile culture media: Nutrient agar, De Man, Rogosa and Sharpe, eosin methylene blue agar, Salmonella-Shigella agar and thiosulphate citrate bile sucrose agar. All media used were prepared according to the manufacturer's instructions.

\section{Gut morphology evaluation}

The gut of $C$. gariepinus juveniles was obtained from five different diet groups in triplicate to examine the gut morphology. They were placed into appropriately labelled plain bottles containing $10 \%$ buffered formalin solution until analysis was done. Appropriate gut sections were washed, dehydrated and embedded in paraffin wax. The tissues were sectioned at $5 \mu \mathrm{m}$ thickness and stained with haematoxylin and eosin for histological examination as described by Bancroft et al. (1996). Each gut was subdivided into three sections (proximal, middle and distal) to measure the villi length, villi width and cryptal depth using a microscope (Olympus CX21, Japan) with X10 objective lens and a graduated eyepiece. Five different villi and crypts were used to compute the mean in triplicate per diet treatment group.

\section{Statistical analysis}

Data were subjected to descriptive statistics, one-way analysis of variance and polynomial regression using the SPSS statistical package for Windows (version 17.0). Duncan's multiple range test was used to evaluate the level of significant differences at $\mathrm{P}<0.05$.

\section{RESULTS}

\section{Proximate composition of the experimental diet}

The crude protein and moisture content of the experimental diets were not significantly different $(P>0.05)$ among the experimental diets. However, the ether extract, ash and nitrogen-free extract content (NFE) increased significantly $(P<0.05)$ with increasing inclusion levels of $P$. pulmonarius stalk meal while the crude fibre of the experimental diets reduced with increasing inclusion level of the mushroom stalk meal.

\section{Growth performance}

The growth performance indices of $C$. gariepinus juveniles fed the diet supplemented with $P$. pulmonarius stalk meal is summarised in Table 2. The initial body weight of the experimental fish was $10.84 \pm 0.04 \mathrm{~g}$. At the end of the experiment, there was no significant difference $(P>0.05)$ in final weight, weight gain, specific growth rate and survival of the fish. However, the production performance index of $C$. gariepinus juveniles fed the experimental diets were significantly higher $(P<0.05)$ compared to the control group. The highest production performance index was observed in PSM $3(68.45 \pm 1.40)$ while the control had the least $(62.40 \pm 1.03)$.

\section{Feed intake and diet utilisation}

The feed intake and diet utilisation indices of $C$. gariepinus juveniles fed the experimental diet are shown in Table 3. There was no significant difference $(P>0.05)$ in the feed intake and feed conversion ratio (FCR); however, the protein efficiency ratio (PER) was significantly higher $(P<0.05)$ in PSM 3 compared to the other diet treatment groups. The total feed intake and FCR ranged from $17.13 \pm 0.52 \mathrm{~g} /$ day (control) to $18.23 \pm 0.47 \mathrm{~g} /$ day (PSM 3) and $0.95 \pm 0.07$ (PSM 3) to $1.02 \pm 0.06$ (control), respectively.

\section{Polynomial regression curve of weight gain}

The regression curve of the weight gain versus the diet treatment is shown in Fig 1 . The optimum inclusion level of $P$. pulmonarius stalk meal in the experimental diet was $6.72 \mathrm{~g} / 100 \mathrm{~g}$ which gave an optimum weight gain of 48.63 $\mathrm{g}$ at week 8 of the feeding trial.

\section{Water quality}

The biweekly water quality profile as observed in the experimental tanks during the feeding trial were within the range: $\mathrm{pH} 7.43 \pm 0.27$ to $7.68 \pm 0.33$, dissolved oxygen $4.43 \pm 0.49$ to $5.00 \pm 0.92 \mathrm{mg} / \mathrm{L}$, ammonia $0.20 \pm 0.06$ to $0.22 \pm 0.09 \mathrm{mg} / \mathrm{L}$, nitrite $0.04 \pm 0.02$ to $0.06 \pm 0.02 \mathrm{mg} / \mathrm{L}$, and temperature $28.21 \pm 0.50$ to $28.32 \pm 0.59^{\circ} \mathrm{C}$.

\section{Gut microbiota}

The microbial growth in the gut of $C$. gariepinus juveniles on selected media as estimated from the different diet treatment groups is presented in Table 4. Quantitatively, there was a significant increase $(P<0.05)$ in the total viable count (TVC) in PSM 2 and 3 diet groups. Lactic acid bacteria (LAB) count in PSM 2, PSM 3 and PSM 4 diet groups were significantly higher than in other diet groups. The diet group PSM 3 had the highest LAB count of 7.03 $\log _{10} \mathrm{cfu} / \mathrm{g}$ while the control had the lowest LAB count of $5.00 \log _{10} \mathrm{cfu} / \mathrm{g}$. 
Table 2. Growth performance indices of Clarias gariepinus fed Pleurotus pulmonarius stalk meal supplemented diet

\begin{tabular}{|c|c|c|c|c|c|}
\hline Parameters analysed & Control & PSM 2 & PSM 3 & PSM 4 & PSM 5 \\
\hline Initial weight (g) & $10.82 \pm 0.05$ & $10.83 \pm 0.03$ & $10.86 \pm 0.03$ & $10.85 \pm 0.04$ & $10.84 \pm 0.04$ \\
\hline Final weight (g) & $48.81 \pm 3.37$ & $50.28 \pm 3.63$ & $53.81 \pm 2.17$ & $51.91 \pm 1.50$ & $51.63 \pm 4.98$ \\
\hline Weight gain (g) & $37.98 \pm 3.32$ & $39.45 \pm 2.15$ & $42.91 \pm 2.15$ & $41.06 \pm 0.85$ & $40.79 \pm 4.98$ \\
\hline Specific growth rate (\%/day) & $2.66 \pm 0.12$ & $2.70 \pm 0.13$ & $2.86 \pm 0.08$ & $2.79 \pm 0.05$ & $2.78 \pm 0.17$ \\
\hline Survival (\%) & $92.00 \pm 2.31$ & $90.67 \pm 2.00$ & $89.33 \pm 6.11$ & $86.67 \pm 2.33$ & $90.67 \pm 2.31$ \\
\hline Production performance index & $62.40 \pm 1.03^{\mathrm{a}}$ & $63.87 \pm 2.31^{\mathrm{ab}}$ & $68.45 \pm 1.40^{c}$ & $63.13 \pm 0.84^{\mathrm{ab}}$ & $65.48 \pm 0.72^{b c}$ \\
\hline
\end{tabular}

The values are means of triplicate data; Means \pm SD with different superscript within the same row are significantly different $(P<0.05)$; $C o n t r o l, P S M 2$, PSM3, PSM4, PSM5 = Pleurotus pulmonarius stalk meal at 0, 2.5, 5.0, 7.5, and $10 \mathrm{~g} / 100 \mathrm{~g}$ inclusion level

Table 3. Feed intake and diet utilisation indices of Clarias gariepinus fed Pleurotus pulmonarius stalk meal supplemented diet

\begin{tabular}{lccccc}
\hline \hline Dietary parameters & Control & PSM 2 & PSM 3 & PSM 4 & PSM 5 \\
\hline Feed intake (g/fish/day) & $0.67 \pm 0.06$ & $0.69 \pm 0.02$ & $0.73 \pm 0.02$ & $0.73 \pm 0.02$ & $0.72 \pm 0.04$ \\
FCR & $1.02 \pm 0.06$ & $0.98 \pm 0.06$ & $0.95 \pm 0.07$ & $0.99 \pm 0.04$ & $0.99 \pm 0.07$ \\
PER & $1.43 \pm 0.02^{\mathrm{a}}$ & $1.45 \pm 0.09^{\mathrm{a}}$ & $1.47 \pm 0.10^{\mathrm{b}}$ & $1.40 \pm 0.06^{\mathrm{a}}$ & $1.41 \pm 0.10^{\mathrm{a}}$ \\
\hline \hline
\end{tabular}

The above values are means of triplicate data; Means \pm SD with different superscript within the same row are significantly different $(P<0.05)$. Control, PSM 2, PSM 3, PSM 4, PSM 5 = Pleurotus pulmonarius stalk meal at 0, 2.5, 5.0, 7.5, and $10 \mathrm{~g} / 100 \mathrm{~g}$ inclusion level. FCR - Feed conversion ratio; PER

- Protein efficiency ratio

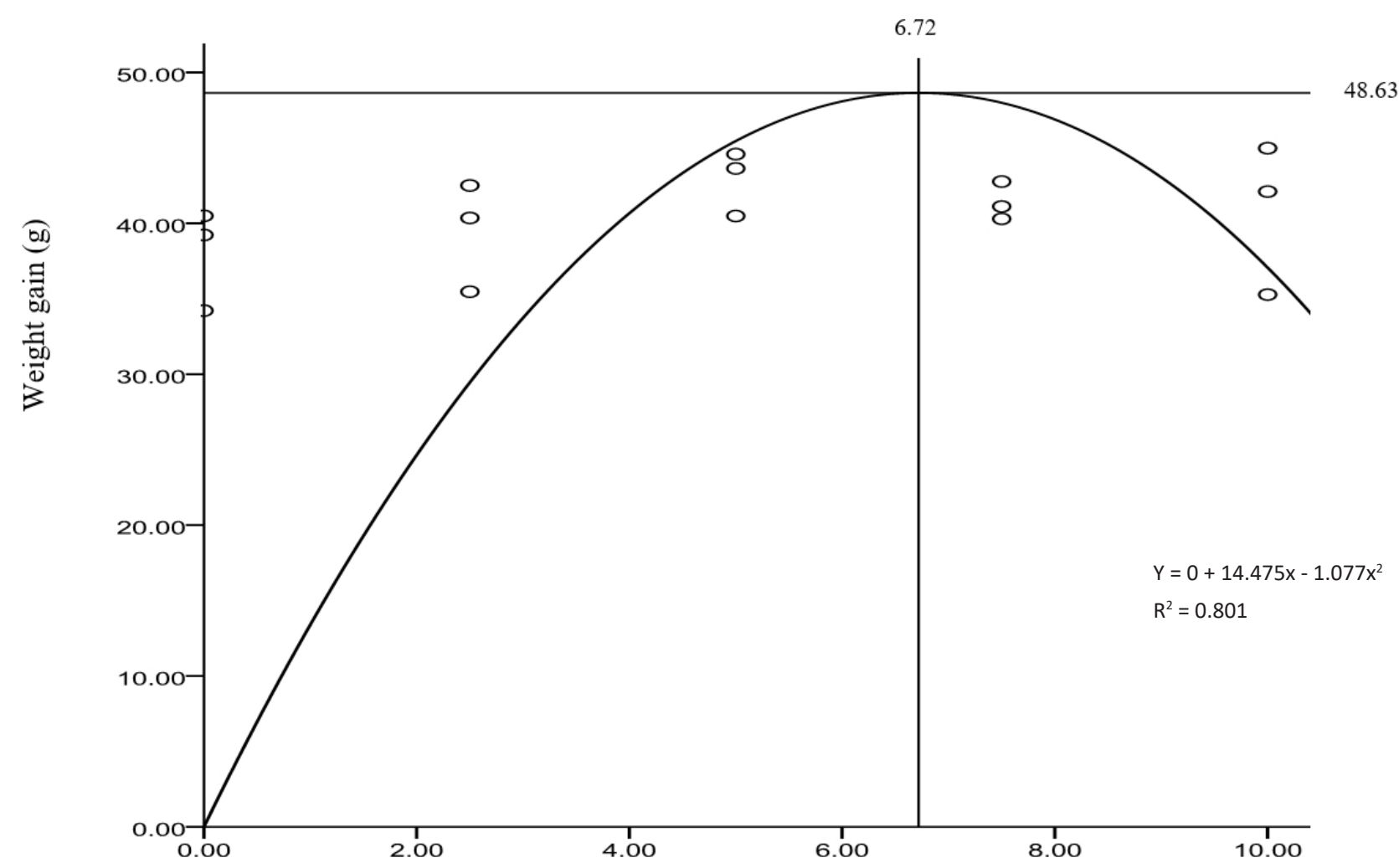

Inclusion level of Pleurotus pulmonarius stalk meal (g/100g)

Fig 1. Relationship of weight gain (g) of Clarias gariepinus and Pleurotus pulmonarius stalk meal inclusion level 
Table 4. Gut microbiota of Clarias gariepinus juveniles fed Pleurotus pulmonarius stalk meal supplemented diet

\begin{tabular}{lccccc}
\hline \hline Diet group & T.V.C. $\left(\log _{10} \mathrm{cfu} / \mathrm{g}\right)$ & Lactic acid bacte-ria $\left(\log _{10} \mathrm{cfu} / \mathrm{g}\right)$ & E. coli & Salmonella spp. & Vibrio spp. \\
\hline PSM 1 (control) & $7.71 \mathrm{a}$ & $5.00 \mathrm{a}$ & + & ++++ & +++ \\
PSM 2 & $7.56 \mathrm{a}$ & $7.01 \mathrm{c}$ & - & +++ & ++ \\
PSM 3 & $7.96 \mathrm{~b}$ & $7.03 \mathrm{c}$ & - & +++ & ++ \\
PSM 4 & $8.34 \mathrm{c}$ & $6.68 \mathrm{~b}$ & - & ++ & ++ \\
PSM 5 & $7.68 \mathrm{a}$ & $5.13 \mathrm{a}$ & - & ++ & ++ \\
\hline \hline
\end{tabular}

Values in the same column with different superscripts are significantly different $(\mathrm{P}<0.05)$.

Key: (-): No microbial growth, (+): microbial growth. ++: Signs that are more positive shows more intensity

T.V.C - Total viable count, PSM 1, PSM 2, PSM 3, PSM 4, PSM 5 = Pleurotus pulmonarius stalk meal at 0, 2.5, 5.0, 7.5, and $10 \mathrm{~g} / 100 \mathrm{~g}$ inclusion level

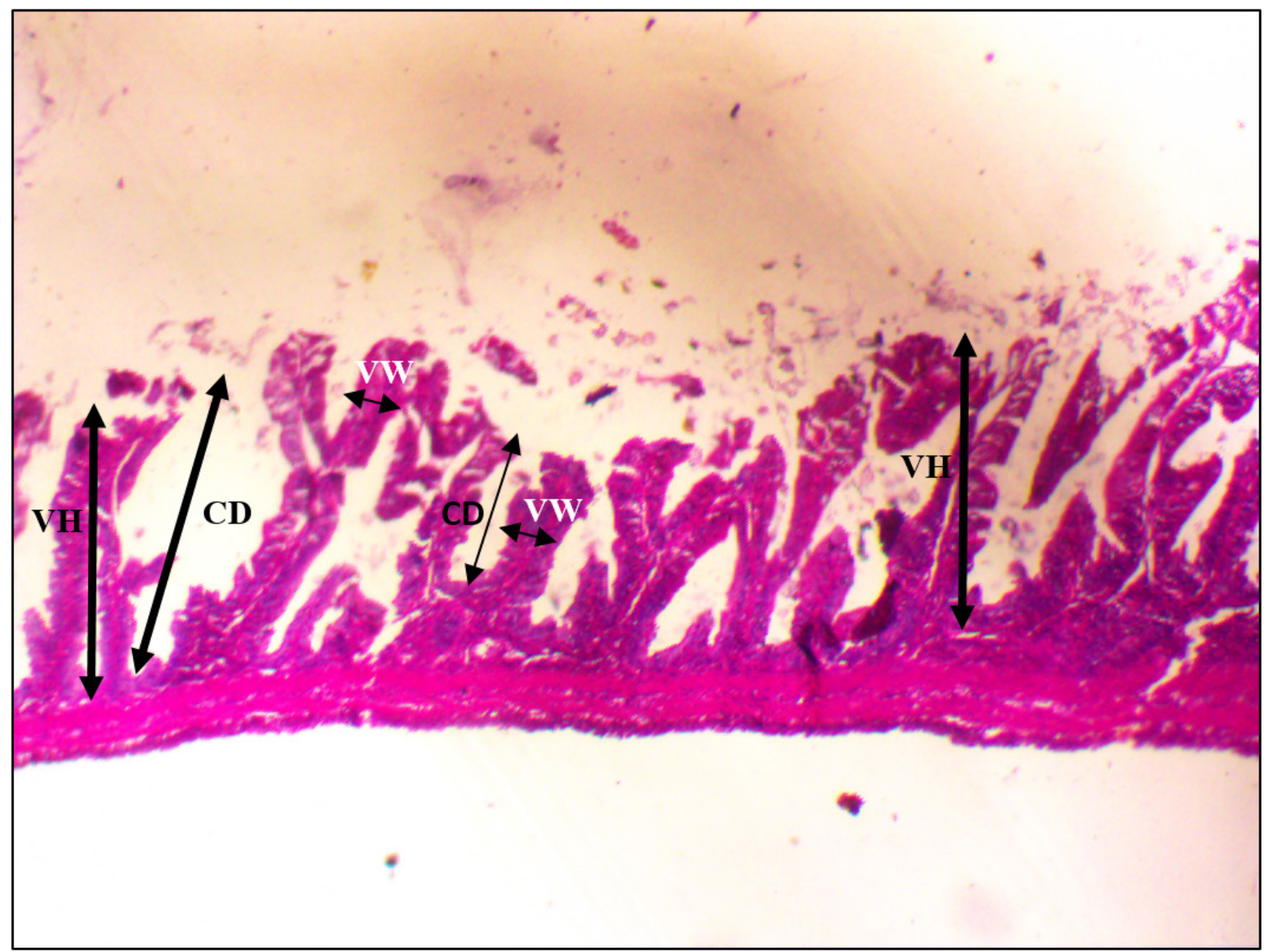

Fig 2. Dissected gut indicating villi height, villi width and cryptal depth of Clarias gariepinus fed Pleurotus pulmonarius stalk meal supplemented diet. VH- villi height, VW- villi width, CD- cryptal depth 
Qualitatively, E. coli was present in the control but absent in the diet supplemented groups while colonies of Salmonella species and Vibrio species were fewer in all the diet supplemented groups compared to the control.

\section{Gut morphology}

The intestinal measurements of the proximal villi length, villi width, cryptal depth, absorption area, middle villi length, villi width, cryptal depth, absorption area and distal villi length, villi width, cryptal depth and absorption area of $C$. gariepinus juveniles fed graded levels of $P$. pulmonarius stalk meal is summarised in Table 5 . The picture of the dissected gut of the fish indicating the villi height, villi width and cryptal depth is presented in Fig 2. There was a significant increase $(P<0.05)$ in the proximal villus length and proximal cryptal depth of the diet treatment groups compared to the control group. The proximal villus length and proximal cryptal depth ranged from $0.75 \pm 0.16 \mathrm{~cm}$ (control) to $1.12 \pm 0.18 \mathrm{~cm}$ (PSM 3) and $0.24 \pm 0.04 \mathrm{~cm}$ (control) to $0.31 \pm 0.09 \mathrm{~cm}$ (PSM 4), respectively. There was no significant difference $(P>0.05)$ in the proximal villus width. The middle villus length and middle cryptal depth significantly increased $(P<0.05)$ in the diet supplemented groups compared to the control group. The highest middle intestinal villus length was observed in fish fed PSM $2(0.85 \pm 0.15 \mathrm{~cm})$ and the least in the control group $(0.68 \pm 0.11 \mathrm{~cm})$. The middle cryptal depth ranged from $0.20 \pm 0.04 \mathrm{~cm}$ (control) to $0.30 \pm 0.24$ $\mathrm{cm}$ PSM 5. There was no significant difference $(P>0.05)$ in the middle villus width. The distal intestinal villus length and distal intestinal cryptal depth were significantly higher $(\mathrm{P}<0.05)$ in the diet supplemented group compared to the control, while the distal villus width was not significantly different $(P>0.05)$. The distal villus length varied between $0.41 \pm 0.14 \mathrm{~cm}$ (control) and $0.85 \pm 0.26 \mathrm{~cm}$ (PSM 4), while the distal cryptal depth ranged between $0.17 \pm 0.03 \mathrm{~cm}$ (control) and $0.29 \pm 0.06 \mathrm{~cm}$ (PSM 4).

There was a significant increase $(P<0.05)$ in the proximal area of absorption and distal area of absorption but the middle area of absorption was not significantly different $(P>0.05)$ in the diet supplemented groups relative to the control groups. The proximal area of absorption ranged from $0.15 \pm 0.06 \mathrm{~cm}$ (control) to $0.22 \pm 0.05 \mathrm{~cm}$ (PSM 3) while distal area absorption varied from $0.08 \pm 0.03 \mathrm{~cm}$ (control) to $0.16 \pm 0.06 \mathrm{~cm}$ (PSM 4).

\section{DISCUSSION}

\section{Proximate composition of experimental diet}

The crude protein content in all the diet groups of this study were within the range postulated by Degnani et al. (1989) and NRC (2011). They reported that the protein requirements for warm water fishes ranged from 38$42 \%$ and $38-55 \%$, respectively. It was also comparable with the report by Nwanna et al. (2014) of $40 \%$ protein requirement for Clarias gariepinus. The difference in the

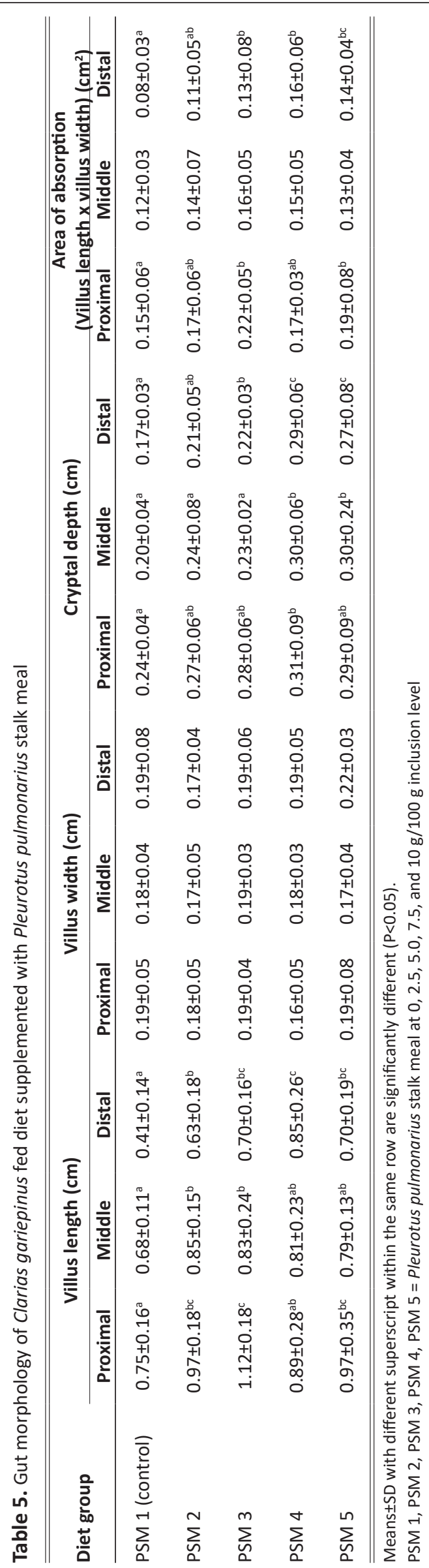

(C) 2020 Author(s). This is an open access article licensed under the Creative Commons Attribution-NonCommercial-NoDerivs License (http://creativecommons.org/licenses/by-nc-nd/3.0/) 
ether extract, crude fibre, ash and NFE may be due to varying the dietary inclusion of non-nutritive cellulose with P. pulmonarius stalk meal in the experimental diet.

\section{Growth performance}

Dietary supplementation with $P$. pulmonarius stalk meal slightly improved the growth performance of fish compared to those fed the control diet; however, it was not significant $(P>0.05)$. The growth performance in this study was in consonance with earlier findings of Jabir et al. (2012), Muin et al. (2014) and Muin et al. (2015) that growth performance of tilapia fingerling (Oreochromis spp) fed Pleurotus sajor caju stalk meal supplemented diets were not significantly different $(P>0.05)$. Similar findings were also found in $C$. gariepinus fingerling fed Pleurous florida stalk meal as rice bran replacement (Muin et al., 2013). Also, Buwjoom and Yamauchi (2005) had a similar observation in broilers fed graded levels of Shiitake mushroom stalk meal. This observation was also in agreement with the observations of Camay (2016) who reported no significant differences in weight gain of broiler chickens fed Pleurotus ostreatus waste powder.

A reduced growth rate was recorded after the peak was reached at $5 \mathrm{~g} / 100 \mathrm{~g}$ inclusion level of $P$. pulmonarius stalk meal (PSM 3). This may be due to some bioactive compounds embedded in $P$. pulmonarius stalk meal such as tannin which could affect the digestibility of nutrients. Also, high fiber content of mushroom may result in lower nutrient intake at higher inclusion level in the present study. Ali and Al-Asgah (2001) suggested that elevated crude fiber content in fish diets may exert a negative effect on nutrients digestibility.

The production performance index is a reflector of production performance of fish as it combines the growth and survival rate of the fish over time (Mohanty, 2004). The diet group PSM 3 had the highest production performance index after which there was a decline. This may indicate that fish fed PSM 3 diet had better weight gain relative to the survival rate in the rearing period of this feeding trial. The significant increase $(P<0.05)$ in the performance index may indicate a positive role of $P$. pulmonarius stalk meal in the diet of $C$. gariepinus.

\section{Feed intake and diet utilisation}

Feed intake is an index of the acceptability of the feed by the fish. It is influenced by the quality of the feed and water quality (White, 2013). The dietary supplementation of $P$. pulmonarius stalk meal did not significantly affect ( $P>0.05)$ feed intake. Buwjoom and Yamauchi (2005) reported quite a similar trend of no significant difference $(P>0.05)$ in broilers fed Shiitake stalk meal supplemented diet at $0,2.5,5.0$, and $7.5 \%$. However, at $10.0 \%$ inclusion level they recorded a significant decrease in feed intake. Feed conversion ratio (FCR) is a major indicator of feed efficiency in aquaculture. It is used to assess the utilisation and absorption of feed and its conversion to flesh by the fish. The FCR of the fish fed different supplemental levels of $P$. pulmonarius stalk meal were similar. This observation followed the same trend with Jabir et al. (2012) and Muin et al. (2014) who observed no significant difference ( $P>0.05$ ) in FCR of tilapia fingerling (Oreochromis species) fed $P$. sajor caju stalk meal supplemented diets as prebiotics and fish meal replacement, respectively.

Protein efficiency ratio (PER) is an indicator of the quality of protein in the feed. There was a significant difference $(\mathrm{P}<0.05)$ in the PER with $5.0 \mathrm{~g} / 100 \mathrm{~g}$ inclusion level of $P$. pulmonarius stalk meal (PSM 3), having the highest PER. However, there was a decline at higher inclusion level of P. pulmonarius stalk meal. The result revealed that at 5.0 $\mathrm{g} / 100 \mathrm{~g}$ inclusion level of $P$. pulmonarius stalk meal (PSM 3), the fish may better utilize the protein in the diet. This was in agreement with the studies on C. gariepinus fingerlings fed $P$. florida stalk meal as rice bran replacement by Muin et al. (2013). However, it contradicted the trend by earlier authors (Jabir et al., 2012; Muin et al., 2014 and Muin et al., 2015) that recorded no significant differences in PER in their study.

\section{Water quality parameter}

The water quality parameters measured during the feeding trial were within the acceptable range for $C$. gariepinus, as postulated by Viveen et al. (1985) and Omitoyin (2007). This study indicated that $P$. pulmonarius stalk meal supplemented diet could be used in the culture of fish because it did not significantly change the water quality in all the experimental aquaria.

\section{Gut microbiota}

The significant increase $(P<0.05)$ in lactic acid bacteria (LAB) count in the gut of $P$. pulmonarius supplemented diet groups may infer that it acted as a substrate (prebiotics) to stimulate the growth and boost the activity of resident $L A B$ in the gut of $C$. gariepinus which are beneficial microorganisms that improve the gut health of the fish.

The presence of $E$. coli in the gut of the control group and its absence in all diet supplemented groups may indicate that $P$. pulmonarius stalk meal inhibited the growth of $E$. coli in the gut of $C$. gariepinus. The absence of $E$. coli in the diet supplemented groups may be due to the production of bacteriocins by lactic acid bacteria. Bacteriocins have been reported to have bacteriocidal activity which has the ability to suppress the growth of potential pathogens (Vijayabaskar and Somasundaram, 2008). In addition, the presence of Salmonella species and Vibrio species colonies was lower in the diet supplemented groups compared to the control group, maybe due to the production of bacteriocins and short-chain fatty acids by lactic acid bacteria which increases the $\mathrm{pH}$ of the gut and makes it non-conducive for pathogenic organisms to strive. The diet may also have reduced the growth of potentially pathogenic organisms in the gut of $C$. gariepinus by competitive inhibition or antagonism due to production of bacteriocin by lactic acid bacteria.

In consonance with the finding of this study, Guo et al. 
(2004) reported that mushroom and herbal extract supplemented diets reduced Bacteroides species, Enterococci and $E$. coli numbers, but increased numbers of Bifidobacteria and Lactobacilli in broilers gut. Patel and Goyal (2012) also reported that prebiotics promoted the growth of lactic acid bacteria in the colon and exerts antagonism to Salmonella species and E. coli, thereby limiting their proliferation. The report of Andrew et al. (2009) was also in agreement with the observation in the present study which surmised that mannanoligosaccharide promoted the growth of beneficial lactic acid bacteria in the intestine and assisted in inhibiting the growth of pathogens by producing bacteriocins. Also in agreement with the present study, Kavyani et al. (2014) and Giannenas et al. (2011) reported that Lactobacillus count was significantly higher $(P<0.05)$ and $E$. coli loads decreased significantly $(P<0.05)$ in broiler chickens and turkey poults fed Agaricus bisporus supplemented diet compared to the control, respectively. However, the present result did not follow the same trend with the reports of Denji et al. (2015) and Rezeghi et al. (2011) who observed no significant difference in intestinal lactic acid bacteria count of rainbow trout (Oncorhynchus mykiss) and beluga (Huso huso) fed mannan-oligosaccharides supplemented diets compared to the control.

\section{Gut morphology}

Gut morphometry is used to evaluate the absorption of nutrients in an organism. The intestinal villi height, middle villi length and cryptal depth showed marked differences $(P<0.05)$ in regional distribution and localization along the intestinal length. The increase in the villi height of the diet supplemented groups compared to the control may indicate an increase in the absorption surface area of the intestine and thus improved absorptive capacity, which may enhance the growth rate in the diet supplemented groups compared to the control.

The significant changes $(P<0.05)$ in the proximal cryptal depth, middle cryptal depth and distal cryptal depth of the diet treatment groups compared to the control may signify enhanced digestion as cryptal depth is responsible for the regeneration of the villi and secretion of electrolytes which enhances water secretion into the intestinal lumen for the purpose of digestion (Bowen, 2011). A higher cryptal depth also indicates efficient digestibility and absorption in the ingested feed (Zhou et al., 2010). It could be inferred that enhanced gut absorptive area and increased cryptal depth recorded in fish fed $P$. pulmonarius stalk meal supplemented diet compared to the control may be due to higher mucosal proliferation activity and greater intestinal glandular activity. This may be a result of the prebiotic properties of the mushroom stalk meal which increases the activity of $L A B$ in the intestine, that attaches to the intestinal epithelium, utilizing large amounts of carbohydrates and producing short-chain fatty acids that stimulate the production of gastrointestinal peptides (EIHaroun et al., 2006; Blottiere et al., 2007).
The result of this study was analogous to those of Salze et al. (2008) and Dimitroglou et al. (2010) who reported that mannan-oligosaccharide supplementation enhanced gut development of cobia larva and increased the absorptive area of gastrointestinal tract of juvenile rainbow trout, respectively. It also agreed with the studies on sub-adult rainbow trout, red drum and hybrid striped bass wherein significant changes were noted in the intestinal fold height, enterocyte height and microvillus length in response to dietary supplementation of mannan-oligosaccharides (Dimitroglou et al., 2009); galacto-gluco-mannas, mannanoligosaccharides, fructo-oligosaccharide and galactooligosaccharides (Zhou et al., 2010) and GroBiotic-A (Angulano et al., 2013). However, in contrast to the result obtained in this study, Kavyani et al. (2014) reported that A. bisporus supplemented diet did not significantly affect the crypt depth, villus height and epithelial thickness of broiler chicks. The short-chain fatty acids produced by LAB stimulate large and small intestinal cell proliferation and consequently may increase brush border digestion and nutrient absorption through increased villus height and crypt depth (Samal and Behura, 2015). P. pulmonarius stalk meal supplemented diet could contribute to increased nutrient absorption and may enhance metabolism of the fish.

\section{CONCLUSION}

Dietary inclusion of $P$. pulmonarius stalk meal did not significantly affect growth performance indices. Perhaps if feeding duration is extended, it may enhance the growth and feed utilization of the fish. However, it favorably boosted resident lactic acid bacteria, reduced the growth of potentially pathogenic organisms and enhanced the gut morphology of $C$. gariepinus.

\section{SAŽETAK}

\section{RAST, MORFOLOGIJA I MIKROFLORA CRIJE- VA AFRIČKOG SOMA Clarias gariepinus PRI HRANIDBI HRANOM SUPLEMENTIRANOM BRAŠNOM OD STABLJIKA GLJIVE Pleurotus pulmonarius}

$\mathrm{U}$ ovom istraživanju ispitan je učinak dodataka brašna od stabljiki gljive Pleurotus pulmonarius na rast, mikrofloru i morfologiju crijeva afričkog soma Clarias gariepinus. Brašno stabljike dodano je u količinama: 0,0 g / 100 $\mathrm{g}$ (kontrola); 2,5 g / $100 \mathrm{~g}$ (PSM 2), 5,0 g / $100 \mathrm{~g}$ (PSM 3), 7,5 g / $100 \mathrm{~g}$ (PSM 4) i 10,0 g / $100 \mathrm{~g}$ (PSM 5). Afrički somovi Clarias gariepinus ( $n=375$ ), s početnom masom od $10,84 \pm 0,04 \mathrm{~g}$, podijeljeni su sa po 25 riba u tankove od 60 litara u potpuno randomiziranom dizajnu za svaki hranidbeni tretman u tri ponavljanja. Hranidbeni pokus 
provodio se osam tjedana. Prirast, specifična stopa rasta, stopa preživljavanja, unos hrane i konverzija hrane se nisu značajno razlikovali između svih hranidbenih skupina. Međutim, indeks uspješnosti uzgoja ribe te indeks proteinske učinkovitosti bio je viši kod riba na PSM 3 dijeti u odnosu na druge tretmane. Ukupni broj održivih bakterija u crijevima kretao se u rasponu od 7,56 (PSM 2) do 8,34 $\log _{10} \mathrm{cfu} / \mathrm{g}$ (PSM 4), dok se broj bakterija mliječne kiseline kretao između 5,00 (kontrola) i 7,03 $\log _{10}$ cfu / g (PSM 3). Escherichia coli je identificirana u crijevima kontrolne skupine, ali nije pronađena kod skupina s dodatcima brašna stabljika gljiva. Pri usporedbi s ostalim hranidbenim skupinama, u kontrolnoj skupini opaženo je više kolonija vrsta Salmonela i Vibrio. Dužina proksimalnih, srednjih i distalnih crijevnih resica, proksimalna, srednja i distalna kriptalna dubina te proksimalno i distalno apsorpcijsko područje ribe hranjene suplementiranom hranom bili su veći od kontrole. Suprotno tome, proksimalna, srednja i distalna širina resica te srednja površina apsorpcije nisu se značajno razlikovali. Unatoč uočenoj povoljnoj mikroflori i histomorfologiji crijeva, kod ribe hranjene brašnom stabljike gljive $P$. pulmonarius, ovi se atributi nisu očitovali $\mathrm{u}$ indeksima rasta.

Ključne riječi: resice, dubina kripta, bakterije mliječne kiseline, gastrointestinalni trakt, gljiva

\section{REFERENCES}

Ahmed, M., Abdullah, N., Shuib, A. S., Razak, S. A. (2017): Influence of raw polysaccharide extract from mushroom stalk waste on growth and $\mathrm{pH}$ perturbation induced-stress in Nile tilapia. Aquaculture, 468, 60-70.

Aida, F. M. N. A., Shuhaimi, M., Yazid, M., Maaruf, A. G. (2009): Mushroom as a potential source of prebiotics: A review. Trends in Food Science and Technology, 20, 567-575.

Ajiboye, O. O., Yakubu, A. F., Adams, T. E. (2012): A Perspective on the ingestion and nutritional effects of feed additives in farmed fish species. World Journal of Fish and Marine Sciences, 4, 1, 87-101.

Andrew, S. R., Sahu, N. P., Pal, A. K., Kumar, S. (2009): Haematological modulation and growth of Labeo rohita fingerlings: effect of dietary mannan oligosaccharide, yeast extract, protein hydrolysate and Chlorella. Aquaculture Research, 41, 61-69.

AOAC (Association of Official Analytical Chemists) (2002): Official Methods of Analysis. $7^{\text {th }}$ Ed.Washington, D.C.

Bancroft, J. D., Stevens, A., Turner, D. R. (1996): Theory and Practice of Histological Techniques. $4^{\text {th }}$ edition, Churchill Livingstone, New York.

Blottiere, H. M., Buecher, B., Galmiche, J. B., Cherbut, C. (2003): Molecular analysis of the effect of shortchain fatty acids on intestinal cell proliferation. The Proceedings of the Nutrition Society, 62, 101-106.

Bowen, R. (2011): Villi, crypts and the life cycle of small intestine enterocytes in pathophysiology of the digestive system. http/www.vivo.colostate.edu/ hbooks/pathophy/ digestive/small gut/lifecycle. html. accessed January 2018.

Buwjoom, T., Yamauchi, K. (2005): Effects of Shiitake mushroom stalk meal on growth performance carcass yield and blood composition in broilers. Journal of Poultry Science, 42, 283-290.

Camay, R. M. (2016): Mushroom (Pleurotus ostreatus) waste powder: Its influence on the growth and meat quality of Broiler chickens (Gallus gallus domesticus). World Journal of Agricultural Research, 4, 4, 98-108.

Chou, W., Sheih, I., Fang, T. J. (2013): The applications of polysaccharides from various mushrooms wastes as prebiotics in different systems. Journal of Food Science, 78, 7, M1041-1048.

Degnani, G., Yilgal, B., Levanon, D. (1989): Effects of different dietary protein level and temperature on feed utilisation and growth of African catfish Clarias gariepinus (Burchell, 1822). Aquaculture, 38, 55-74.

Denji, K. A., Mansour, M. R., Sh. Ghobadi, R. A., Jafarpour, S. A., Mirbeygi, S. K. (2015): Effect of Dietary prebiotic mannan oligosaccharide (MOS) on growth performance, intestinal microflora, body composition, haematological and blood serum biochemical parameters of Rainbow Trout (Oncorhynchus mykiss) Juveniles. Journal of Fisheries and Aquatic Science, 10, 255-265.

Dimitroglou, A., Merrfield, D. L., Spring, P., Sweetman, J., Moate, R., Davies, S. J., (2010): Effects of mannan oligosaccharide (MOS) supplementation on growth performance feed utilisation, intestinal histology and gut microbiota of Gilthead sea bream (Sparus aurata). Aquaculture, 300, 182-188.

Dimitroglou, A., Merrifield, D. L., Moate, R., Davies, S.J., Spring, P., Sweetman, J., Bradley, G. (2009): Dietary mannan oligosaccharide supplementation modulates intestinal microbial ecology and improves gut morphology of Rainbow trout, Oncorhynchus mykiss (Walbaum). Journal of Animal Science, 87, 3226-3234.

El-Haroun, E. R., Goda, A. M., Kabir Chowdhury, M. A. (2006): Effect of Dietary probiotic Biogen supplementation as a growth promoter on growth performance and feed utilization of Nile tilapia Oreochromis niloticus (L.) Aquaculture Research, 37, 1473-1480.

Fard, S. H., Toghyani, M., Tabeidian, S. A. (2014): Effect of Oyster mushroom wastes on performance, immune responses and intestinal morphology of Broiler chickens. International Journal of Recycling of Organic waste in Agriculture, 3, 4, 141-146.

Ganguly, S. Paul, I., Mukhopadhayay, S. K. (2010): Immunostimulant, probiotic and prebiotics: their applications and effectiveness in aquaculture. Israeli Journal of Aquaculture-Bamigeh, 62, 3, 130-138. 
Giannenas, I., Pappas, I. S., Mavridis, S., Kontopidis, G., Skoufos, J., Kyriazakis, I. (2010): Performance and antioxidant status of broiler chickens supplemented with dried mushroom (Agaricus bisporus) in their diet. Poultry Science, 89, 303-311.

Giannenas, I., Tsalie, E., Chronis, E. F., Mavridis, S., Tontis, D., Kyriazakis, I. (2011): Consumption of Agaricus bisporus mushroom affects the performance, Intestinal microbiota composition and morphology and antioxidant status of turkey poults. Animal Feed Science and Technology, 165, 218-229.

Guillamon, E., Garcia Lafuente, A., Lozano, M., D Arrigo, M., Rostagno, M. A., Villares, A., Martinez, J. A. (2010): Edible mushrooms: role in the prevention of cardiovascular diseases. Fitoterapia, 81, 715723.

Guo, F. C., Williams, B. A., Kwakkel, R. P., Li, H. S., Li, X. P., Luo, J. Y., Li, W. K., Verstegen, M. W. A. (2004): Effects of mushroom and herb polysaccharides, as alternatives for an antibiotic, on the cecal microbial ecosystem in broiler chickens. Poultry Science, 83, 175-182.

Hoa, H. T., Wang C. (2015): The effects of temperature and nutritional conditions on mycelium growth of two Oyster Mushrooms (Pleurotus ostreatus and Pleurotus cystidiosus). Mycobiology, 43(1):14-23.

Jabir, M. D. A. R., Razak, S. A., Vikineswary, S. (2012): Effect of mushroom supplementation as a prebiotic compound in superworm based diet on growth performance of Red Tilapia fingerlings. Sains Malaysiana, 41, 10, 11971203.

Kavyani, A., Shahne, A. Z., Pourreza, J., Hajiabadi, S. M. A. J., Nikkhah, M., Landy, N. (2014): Efficiency of different levels of Mushroom (Agaricus Bisporus) on intestinal morphology and microflora of Broiler chickens. Journal of Farm Animal Nutrition and Physiology, 48, 3, 39-151.

Mohanty, R. K. (2004): Density-dependent growth performance of Indian major carps in rainwater reservoirs. Journal of Applied Ichthyology, 20, 2, 123127.

Muin, H., Abdul Fatah, N. N., Bahari I. H., Abdul Razak, S. (2014): Replacement of rice bran with Pleurotus florida stalks on growth performance of Oreochromis Niloticus fingerlings. Sains Malaysiana, 43, 5, 675-681.

Muin, H., Abdul Fatah, N. N., Mohd Nor, H. M., Abdul Razak, S. (2013): Rice bran replacement in Clarias gariepinus fingerlings diet with Pleurotus florida stalks. Sains Malaysiana, 42, 8, 1109-1114.

Muin, H., Taufek, N. M., Abiodun, R. A., Yusof, H. M., Abdul Razak, S. (2015): Effect of partial and complete replacement of fishmeal with mushroom stalk meal and soy bean meal on growth performance of Nile tilapia, Oreochromis niloticus fingerlings. Sains Malaysiana, 44, 4, 511-516.

National Research Council. [NRC] (2011): Nutrient requirements of fish and shrimp. The National Academy Press. Washington DC. United States of America, 326328.
Nwanna, L. C., Omojola, E., Nwanna, E., Abiodun, E. (2014): Effect of protein deficient diets on the growth and carcass protein ash ratio of African catfish Clarias gariepinus (BURCHELL 1822). Journal of Applied Science and Environmental Management, 18, 3, 537541.

Ogunshe, A. A. O., Olabode, O. P. (2009): Antimicrobial potentials of indigenous Lactobacillus strains on gram-negative indicator bacterial species from Clarias gariepinus (Burchell, 1822) microbial inhibition of fish-borne pathogens. African Journal of Microbiology Research, 3, 12, 870-876.

Omitoyin, B. O. (2007): Introduction to fish farming in Nigeria. Ibadan University Press, Ibadan.

Patel, S., Goyal, A. (2012): The current trends and future perspectives of prebiotics research: A review. Biotechnology, 2, 2, 115-125.

Razeghi, M. M., Akrami, R., Ghobadi, S. H., Denji, K.A., Ezatrahimi, N., Gharaei, A. (2011): Effect of Dietary mannan oligosaccharide (MOS) on growth performance, survival, body composition and some haematological parameters in giant Sturgeon juvenile (Huso huso Linnaeus, 1754). Fish Physiology and Biochemistry, 38, 829-835.

Reza, A., Abdolmajid, H., Abbas, M., Abdulmohammad, A. K. (2009): Effect of Dietary prebiotic inulin on growth performance, intestinal microflora, body composition and hematological parameters of juvenile Beluga, Huso huso (Linnaeus, 1758). Journal of World Aquaculture Society, 40, 771-779.

Salze G., MacLean E., Schwarz M. H., Craig, S. R. (2008): Dietary mannan oligosaccharide enhances salinity tolerance and gut development of larval Cobia. Aquaculture, 274, 148-152.

Samal, L., Behura, N. C. (2015): Prebiotics: An emerging nutritional approach for improving gut health of livestock and poultry. Asian Journal of Animal and Veterinary Advances, 10, 724-739.

Toghyani, M., Tohidi, M., Gheisari, A., Tabeidian, A., Toghyani, M. (2012): Evaluation of Oyster mushroom (Pleurotus ostreatus) as a biological growth promoter on performance, humoral immunity and blood characteristics of broiler chicks. Japan Poultry Science Association, 49, 3, 183-190.

Vijayabaskar, P., Somasundaram, S. T. (2008): Isolation of bacteriocin producing lactic acid bacteria from fish gut and probiotic activity against common fresh water fish pathogen Aeromonas hydrophila. Biotechnology, 7, 124-128.

Viveen, W. J. A. R., Richter, C. J. J., Van Oordt, P. G., Janssen, J. A. L. and Huisman, E. A. (1985): Practical manual for the African Catfish, Clarias gariepinus. Directorate General for International Cooperation. The Haque, The Netherlands. pp . 94.

White, P. (2013): Environmental consequences of poor feed quality and feed management. In M.R. Hasan and 
M.B. New, eds. On-farm feeding and feed management in aquaculture. FAO Fisheries and Aquaculture Technical Paper, 583, $553-564$.

Zhou, Q. C., Buenlello, J. A., Gatlin, D. M. (2010): Effects of dietary prebiotics on growth performance, immune response and intestinal morphology of Red drum (Sciaenops ocellatus). Aquaculture, 309, 253-257. 